Invited paper for:

CeIl Growth, C. Nicolini, ed.,

Plenum Press

$$
\begin{aligned}
& \text { CONF-8010221--1 } \\
& \text { DE82 } 001469
\end{aligned}
$$

GENE MUTATION, QUANTITATIVE MUTAGENESIS, AND MUTAGEN SCREENING IN MAMMALIAN CELLS: STUDY WITH THE CHO/HGPRT SYSTEM

\author{
Abraham W. Hs le \\ Blology Division, Oak Rigge Nacional Laboratory, \\ Oak R1dge, Tennessee 37830
}

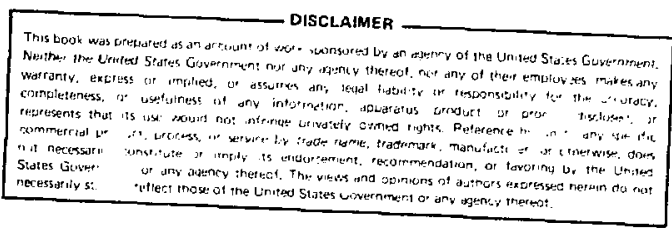

By acceptance of this article, the publisher or reclplent acknowledges the U. S. Government's right to retain a nonexclusive, royalty-free license in and to any copyright covering the article.

Research sponsored by the Office of Health and Environmental Research, U. S. Department of Energy, under contract W-7405-eng-26 with the Unton Carbide Corporation. 
Send proof to: Dr. Abraham W. Hsie

Biology Division

Oak Ridge Nationa1 Laboratory

Post Office Box Y

Oak Ridge, Tennessee $\mathbf{3 7 8 3 0}$ 
GENE MUTATION, QUANTITATIVE MUTAGENESIS, AND MUTAGEN SCREENING IN

MAMMALIAN CELLS: STUDY WITH THE CIIO/HGPRT SYSTEM

\author{
Abraham W. Hs le \\ Biology Division, Oak Ridge National Laboratory, \\ Oak Ridge, Tennessee $\mathbf{3 7 8 3 0}$
}

Summary

We have employed CHO cells to develop and define a set of stringent conditions for studying mutation induction to TG resistance. Several lines of evidence support the CHO/HGPRT system as a speciftc-locus mutatational assay. The system permits quantification of mutation at the HGPRT locus induced by various physical and chenical mutagens. The quantitative nature of the system provides a basis for the study of structure-furction relationships of various classes of chemical mutagens. The intraand interlaboratory reproducibility of this system suggests its potential for screening environmental agents for mutagenic activity.

\title{
Introduction
}

Recent advances in the molecular genetics of bacteria have to a large extent been attributed to the fact that mutants of desirable phenotypes can be readily isolated from haploid miccorganisms. Since the successful cloning of a near-diploid Chinese hamster ovary (CHO) cell line over two decades ago ( 1 ) there has been interest in utilizing CHO and other cells for studying mechanisms of mammalian genetics. Because the great maforfty of mammalian genes exist in the diploid state, it has not

Research sponsored by the Office of Health and Environmental Research, U. S. Department of Energy, under contract W-7405-eng-26 with the Union Carbide Corporation. 
been feasible to isolate recessive mutants, which are the predominant mutant type.

Mutagen-1nduced cell varlants with altered nuteitional requirements and drug sensitivity were first demonstrated in CHO (2) and V79 (3) cells. These successful 1solations were attributed to, in the case of CHO auxotrophs, the hemizygosity of the affected genes (2), and in V79 drug-resistant varlants, locaif zation of the affected gene, hypoxanthine-guanine phosphoribosyl transferase (hgprt), on the functionally monosonic $X$ chromosome (3). Many mutants with other phenotypes have since been is oiated and characterized from these and other cells $(4,5)$.

In this review, I will briefly discuss the CHO/HGPRT system (6-9), a system affecting HGPRT activity in CHO cells, to illustrate studies of gene mutation, quantitative mutagenesis, and mutagen screening. For studies of the genetic, biochemical, and molecular basis of gene mutation, isolation of one or a few mutants of the df Ired phenotypes would be sufficient; however, studies of quant.tative mutagenesis require that a mutational protocol select for mutants a great majority (or al1) of which are affected at a single gene. For mutagen screening a quantitative single-locus mutational as say must also demonstrate its intra- and inter laboratory reproducibility (6).

\section{The CHO/HGPRT system}

For most of our studies, we used $\mathrm{CHO}-\mathrm{K}_{1}-\mathrm{BH}_{4}$ cells (7), a subclon:s of the near-diploid CHO cell line. CHO cells are genetically well characterized and are readily synchronized by various physical and chemical means. These cells exhibit a high cloning efficiency and a relatively stable karyotype. They grow well elther on solid substrate or in suspension with a population doubling tine of 12-14 hr. In addition to being used extensively for studying mutagen-induced cytotoxicity and gene mutation, CHO cells have also been favored for cytogenetic studies.

We have previously standardized the experimental procedures for cell culture, treatment with chemicals, and measurement of cytotoxicity and gene mutation. These are presented briefly in Fig. 1, We measure gene mutation by quartifying the frequency of mutants resistant to a purine analogue, 6-thloguanine (TG). The CHO/HGPRT system has been defined in terms of medium, $\mathrm{pH}$, TG concentration, optimai cell density for selection, recovery of the presumptive mutants, and expreasion time for the mutant phenotype (6-8). A metabolic activation system derived from Aroclor 1254-preinduced male Sprague-Dawley rat livers has been used to determine the mutagenicity of promutagens $(6,8,9)$. Since mutant selection is based on the loss of HGPRT, a phenotypic delay 
is expected; maximum stable expression of the TG-resistance phenotype is reached 7-9 days after mutation induction and remains constant for a diverse spectrum of mutagens such as ethyl methanesulfonate (EMS), N-methyl-N'-nit ro-N-nitros oguanidine, ICR-191, ICR-170, dimethylnitrosamine, benzo(a)pyrene, ultravjolet light, and $\mathrm{Cr}(\mathrm{VI})\left(\mathrm{K}_{2} \mathrm{CrO}_{4}\right)(6,10)$.

Early studies of mammalian cell mutagenesis have questioned the genetic vs epigenetic origin of phenotypic variants. In the absence of direct evidence of gene mutation through analyses of the nucleotide sequence of the hgprt gene and the amino acid sequence of the HGPRT protein for TG-resistant mutants, the following indirect evidence Indicates that the CHO/HGPRT system fulfills the criterta for a specific-locus mutational assay $(6,10,11)$.

A. There is a low spontaneous mutation frequency of $0-20 \times 10^{-6}$ mutants/clonable ce.11 in $\sim 95 \%$ of 500 determirations.

B. Fluctuation analyses of spontaneous mutation demonstrate that the TG-resistance phenotype appears randomly at a rate of $2-4 \times 10^{7}$ mutations/ce11/generation.

C. The TG-resistance phenotype is stable for over 100 genorations among 200 independent isoiated mutants.

D. Physical and chemical mutagens induce TG-resistant mutants with a linear dose-response relationship, and mutants with a temperature-sensitive TG-resistance phenotype have been isolated.

$E$. The spontaneous reversion frequency is $0-1 \times 10^{-7}$ mutants/ clonable cells.

F. Mutagen-1nduced TG resistance $\ln$ near-tetraploid CHO cells occurs at a low frequency, as expected for cells with two functional $\mathrm{X}$ chromosomes.

G. Some TG-resistant mutants are revertible to azaserine resistance after treatment with chemical mutagens; some revertants exhibit HGPRT activity with altered thermosensitivity and kinetic properties.

H. HGPRT activity is altered in a large number of independently. derived TG-resistant mutants.

1. Sensitivity to aminopterin $(1170 / 1180=98 \%)$.

2. Reduction of hypoxanthine incorporation into cellular macromolecules $(184 / 187=98 \%)$.

3. Reduced or altered HGPRT enzyme activity in cell-free extracts $(96 / 98=98 \%)$.

Quantitative Mutagenesis with the CHO/HGPRT System

The quantitative nature of this system was evident from mutagenesis experiments performed over 6 years ago employing a direct-acting chemical mutagen, EMS (6-11) and a physical agent, ultraviolet light (12). With EMS we found that mutation induction 
with a treatment time of $16 \mathrm{hr}$ occurred over the entire survival curve $(7,13,14)$. Further studies using treatment times of $2-24 \mathrm{hr}$ and varying EMS concentrations demonstrated the existence of a limfted reciprocity of EMS mutagenesis; that is, when different combinations of EMS concentrations $(0.05-3.2 \mathrm{mg} / \mathrm{m} 1)$ are multiplied by varying treatment times $(2-10 \mathrm{hr})$, the product $[(\mathrm{mg} / \mathrm{ml}) \cdot \mathrm{hr}]$ yields a constant mutation frequency and cytotoxicity (13). Since 1974 our laboratory has studied the mutagenicity of more than 100 chemical and physical agents (6).

The quantitative nature of the system permits studies of structure-mutagenicity of various classes of direct-acting mutagens, and when the system is coupled with a liver S9-metabolic activation system, promutagens can also be studied $(6,9)$. In analyzing mutagenesis data we describe the mutagenic activity as the number of mutants per $10^{6}$ clonable cells induced by 1 MM of chemical tested. These results listed below iugether with determinations of chemically induced DNA lesions $(14,15)$ provide some insights on the mechanisms of chemical mutagenesis.

A. Analyses of 10 alkylating chemicals reveal that their mutagenicity decreases with increasing size of the alkyl group; methylating agents are 3-6 times more mutagenic than the corresponding ethylating agents $(16,17)$.

B. Studies of 19 heterocyclic mustards (ICR compounds) show that compounds with the tertiary amine side chain are more mutagenic than those with secondary amine side chain $(18,19)$.

C. Of 6 platinum (II) chloroamines studied, $\mathrm{cls}-\mathrm{Pt}\left(\mathrm{NH}_{3}\right)_{2} \mathrm{Cl}_{2}$ is mutagenic whereas its steric isomer, trans-Pt $\left(\mathrm{NH}_{3}\right)_{2} \mathrm{Cl}{ }_{2}$, exhibits highly reduced mutagenicity (15).

D. The mutagentc activity of quinolines is 4-nitroquinoline1-oxide > quinoline > 4-aminoquinoline-1-oxide> 8-aminoquinoline > hydroxyquinoline, 8-nitroquinoline, and dichloroquinoline (San Sebastian, J. R., and Hsie, A. W., unpublished results).

E. While diphenylnitrosamine does not appear to be mutagenic, dimethylnitrosamine and diethylnitrosamine exhibit similar mutagenicity (San Sebastian, J. R., and hsle, A. W., unpublished results).

F. The mutagenicity of haloethanes increases with increasing bromination, i.e., ethylene dibromide > ethylene bromochloride > ethylene dichloride (20).

\section{Mutagen Screening with the CHO/HGPRT System}

We have routinely used EMS as a positive control for directacting mutagens and found that EMS at $200 \mathrm{\mu g} / \mathrm{ml}_{6}$ for a treatment time of $5 \mathrm{hr}$ consistently yields 300 mutancs $/ 10^{6}$ clonable cells with a $15 \%$ standard error (6-20). Several laboratorles such as 
those at DuPont Co., Chemical Industry Institute of Technology, Allied Chenical Co., Carnegle-Mellon Institute, Inhalation Toxicology Research Instltute, etc. have used the CHO/HGPRT system as an integral part of their toxicology research and obtained similar results with EMS. Demonstration of the intra- and interlaboratory reproducibility in studies with standard mutagens such as EMS emphasizes the reliability of the CHO/HGPRT sys sem for quantitative mutagenesis and mutagen screening.

The sensitive, quantitative, and reproducible results obtained from over 80 standard chemtcal and physical agents encouraged us to employ the CHO/HGPRT system to screen for the mutagenic activity of over 30 chemicals, some of which exist as organic mixtures $(21,22)$. For example, we have shown that the acetone fraction of a coal-liquified crude ofl which contalns polycyclic aromatic primary amines and pclycyclic aromatic nitrogen heterocyclics is the major contributor to the mutagenic act tvity of synthetic oll (22); thus, the system appears to be useful for determination of mutagenicity of organic mixtures and for corrohoration of results from other biological. assays.

Ackrowledgements

I thank my colleagues P. A. Brimer, D. B. Couch, P. L. Forbes, A. W. Fuscoe, A. P. L1, M. H. Hsie, N. P. Johnson, R. Machanof:, J. P. O'Neill, J. R. San Sebastian, R. L. Schenley, C. H. Schroder, E. - L. Tan, and K. R. Tindall for experimental work and B. S. Hass, C. A. Jones, R. Machanof f, and R. L. Schenley for manuscript review.

\section{References}

1. Puck, T. T. and Marcus, P. I. (1955) Proc. Natl. Acad. Sc1. USA 41, 432-437.

2. Puck, T. T. and Kao, F.-T. (1967) Proc. Nat1. Acad. Sc1. USA $58,1227-1234$.

3. Chu, E. H. Y. and Malling, H. V. (1968) Proc. Mat1. Acad. Sci. USA $61,1306-1312$.

4. Thompson, L. H. and Baker, R. M. (1973) In Prescott, D. M. (ed.), Methods in Cell Biology, Academic Press, New York, pp 209-281.

5. Siminovitch, L. (1976) Cel1 7, 1-11.

6. Hsie, A. W. (1980) In Williams, G. M., Kroes, R., Waaljers, H. W. and Van de Poll, K. W. (eds.), Predictive Value of Short-Term Screening Tests in Carcinogenicity Evaluation, Elsevier/North-Holland Biomedical Press, Amsterdam/New York/0xford, pp 89-102.

7. Hsie, A. W., Brimer, P. A., Mitche11, T. J. and Gosslee, D. G. (1975) Somat. Cell Genet. 1, 247-261.

8. O'Neil1, J. P., Brimer, P. A., Machanoff, R., Hi rsch, G. P. and Hsie, A. W. (1977) Mutat. Res. 45, 91-101. 
9. Machanoff, R., D'Nel11, J. P., San Se bastlan, J. R., Brimer, P. A. and Hsie, A. W. (1980) Proc. 11th Annu. Meet. Environ. Mutagen Soc., Mar. 16-19, 1980, Nashville, TN, p 102.

10. Hsie, A. W., O'Ne111, J. F., Couch, D. B., San Sehastian, J. R.,

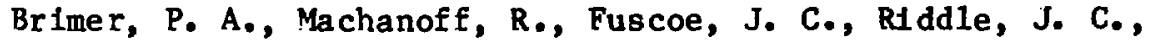
Li, A. P., Forbes, No L. and Hste, A. W. (1978) Radiat. Res. 76, $471-492$.

11. Hsie, A. W., Brimer, P. A., Machanoff, R. and Hsle, M. H. (1977) Mutat. Res. 45, 27 1-282.

12. Hsie, A. W., Brimer, P. A., Mitchel1, T. J. and Gosslee, D. G. (1975) Somat. Ce11 Genet. 1, 383-389.

13. O'Ne111, J. P. and Hsle, A. W. (1977) Nature 269, 815-817.

14. Thlelman, H. -W., Schroder, C. H., O'Nell1, J. P. and Hsie, A. W. (1979) Chem.-B1ol. Interact. 26, 233-243.

15. Johns on, N. P., Hoeschele, J. D., Rahn, R. O., O'Ne111, J. P. and Hsie, A. W. (1980) Cancer Res. 40, 1463-1468.

16. Couch, D. B. and Hsie, A. W. (1978) Mutat. Res. 57, 209-216.

17. Couch, D. B., Forbes, N. L. and Hsie, A. W. (1978) Mutat. Res. $57,217-224$.

18. O'Ne111, J. P., Fuscoe, J. C. and HsIe, A. W. (1078) Cancer Res. 38, 506-509.

19. Fuscoe, J. C., O'Ne1l1, J. P., Peck, R. M. and Hsle, A. W. (1979) Cancer Res. 39, 4875-4881.

20. Tan, E.-L. and Hsle, A. W. (1980) Proc. 11th Annu. Meet. Environ. Mutagen Soc., Mar. 16-19, 1980, Nashville, TN, p 56.

21. Hsie, A. W., Brimer, P. A., O'Ne111, J. P., Epler, J. L., Guerin, M. R. and Hsie, M. H. (1980) Mutat. Res. 78, 79-84.

22. Hsie, A. W., O'Ne111, J. P., Machanoff, R., Schenley, R. L. and Brimer, P. A. (1981) In de Serrea, F. J. (ed.), International Programs for the Evaluation of Short-Term Tests for Carcinogenicity (in press). 
9

Figure 1. The GHO/HGPRT system. 
I. ENZYME

Hypoxanthine or Guanine $\longrightarrow$ HGPRT
6-TG or $8-A G$

11. SYSTEM

(a) wild type $\frac{\text { mutation }}{\text { (induced by physical }} \rightarrow$ variant cell or chemical mutogens)

$\begin{array}{ll}\text { genolype hgprt } & { }^{+} \\ \text {phenotype } \mathrm{TG}^{5}, & \text { hgprt }^{-} \\ \text {ominopterin (or azoserine) } & \mathrm{TG}^{\prime}, \\ \text { positive } & \text { aminopterin (or azcoseririe) } \\ \text { negotive }\end{array}$

(b) Voriont selection is bissed on resistonce to TG

(c) Selection of revertanis is bosed on growth in the presence of ominop!erin or azoserine.

lil. PROTOCOL

DAY

$-1$

0

7

8

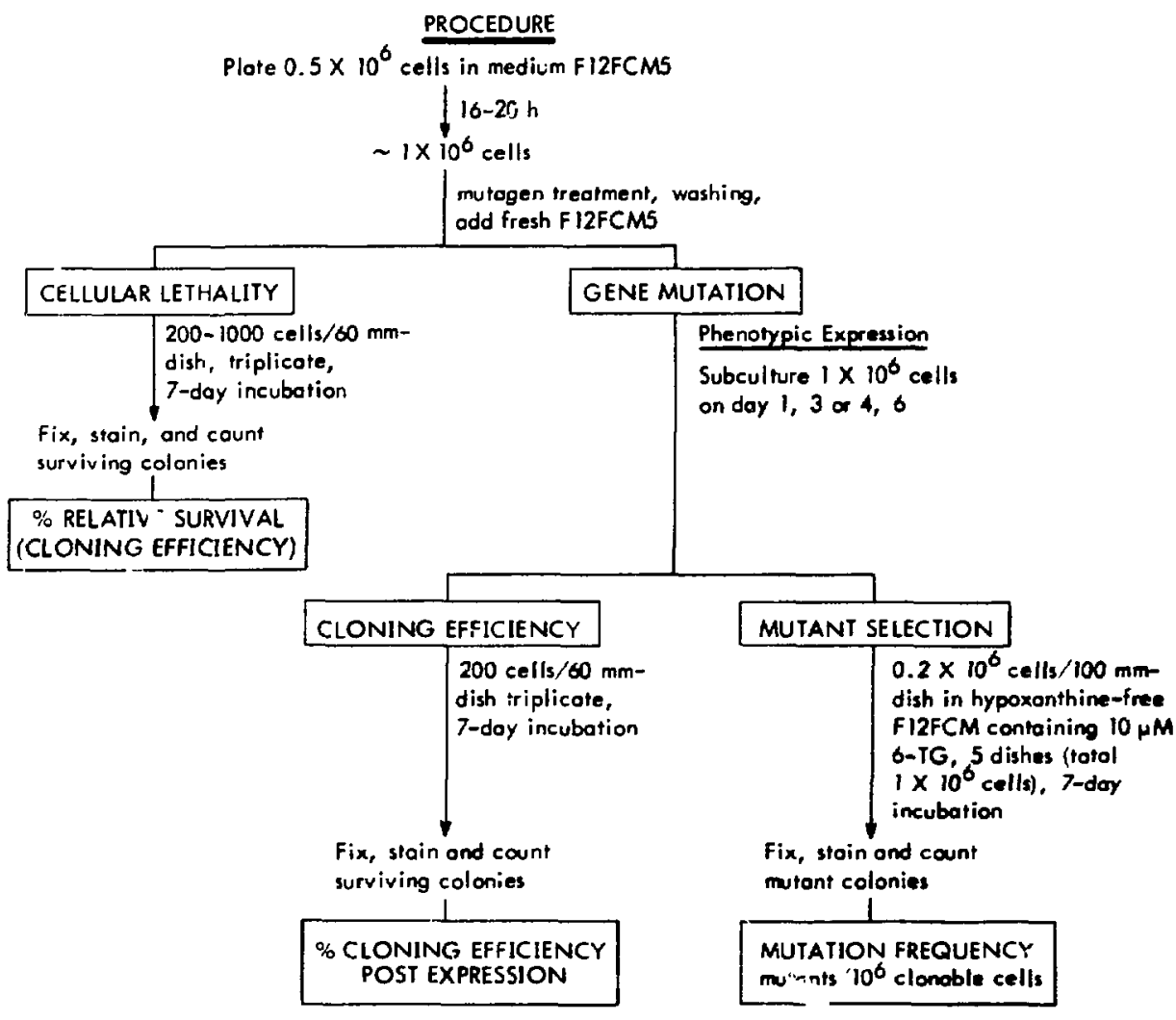

